\title{
History of the Meteorologische Zeitschrift
}

\author{
STEFAN EMEIS*
}

Institute for Meteorology and Climate Research, Forschungszentrum Karlsruhe, Germany

(Manuscript received July 4, 2008; in revised form September 22, 2008; accepted September 26, 2008)

\begin{abstract}
In 1884, one year after the foundation of the German Meteorological Society, the first volume of the Meteorologische Zeitschrift was published. Merged with the respective Austrian journal two years later it existed for a first period until 1944. Following several separate publications in the post-war period after 1945 Meteorologische Zeitschrift was re-founded in 1992 as a joint publication of the Austrian, the Swiss, and the German Meteorological Societies. This paper gives an overview on the history of this journal, its recent developments, and the persons involved in editing.
\end{abstract}

\section{Zusammenfassung}

1884, ein Jahr nach der Gründung der Deutschen Meteorologischen Gesellschaft, erschien der erste Jahrgang der Meteorologischen Zeitschrift. Zwei Jahre später mit dem österreichischen Pendant zusammengelegt, dauerte ihre erste Publikationsphase bis 1944. Nach einigen separaten Publikationen in der Nachkriegszeit nach 1945 wurde die Meteorologische Zeitschrift 1992 als gemeinsame Publikation der österreichischen, schweizerischen und deutschen Meteorologischen Gesellschaften wiederbegründet. Diese Arbeit gibt einen Überblick über die Geschichte dieser Zeitschrift und über die bei der Herausgabe beteiligten Persönlichkeiten.

\section{Introduction}

Scientific journals have been published for more than 400 years now. They emerged from the correspondence between scholars (ZOTT, 2003) when it became obvious that classical letters were no longer sufficient for communication within a growing scientific community. The first journals were the Journal des Sçavants, which appeared for the first time on January 5, 1665 in Paris, and, a few months later, the Philosophical Transactions in London. In Germany the publication of scientific journals started in 1682 with the Acta Eruditorum (Acts of scholars) which were issued in Latin in Leipzig on a monthly basis. In 1688, the Monatsgespräche followed which were edited by Christian Thomasius in the German language in Halle. The origin of scientific journals is thus closely related to the onset of the age of enlightenment.

Scientific journals had already been established as a means of publication before the formation of the scientific disciplines in their present shape began around the turn to the $19^{\text {th }}$ century. Meteorology was not even a separate discipline in the first half of the $19^{\text {th }}$ century but still part of physics as can be seen from the history of meteorological textbooks (EMEIS, 2006). Therefore the first scientific papers on meteorology in Germany are to be found in Gren's Journal der Physik (1790-1794) or in Gilbert's Annalen der Physik (from 1799 on). This situation lasted until about 1870 when meteorology finally became an autonomous scientific discipline.

\footnotetext{
${ }^{*}$ Corresponding author: Stefan Emeis, Institute for Meteorology and Climate Research, Forschungszentrum Karlsruhe, Kreuzeckbahnstr. 19, 82467 Garmisch-Partenkirchen, Germany.stefan.emeis@imk.fzk.de
}

An outcome of the disentanglement of meteorology from physics was the foundation of the Austrian Society for Meteorology (ÖGM) in 1865 and - now 125 years ago - of the German Meteorological Society (DMG) in 1883. Both societies were devoted to the support of scientific communication and immediately founded scientific journals in their field (Fig. 1). This occurred nearly simultaneously with the establishment of other journals of larger meteorological societies in Europe and North America. In 1873 the first issue of the Quarterly Journal of the Royal Meteorological Society and in 1884 the respective issue of the American Journal of Meteorology were published. The publishing activities especially of the Austrian and German Meteorological Societies were so closely intertwined that in the following only a common presentation is possible.

\section{Foundation of the Austrian and German journals in 1866 and 1884}

Concurrently with the foundation of the ÖGM, the publication of the Zeitschrift der Österreichischen Gesellschaft für Meteorologie was started in Vienna in 1866 (Fig. 2). The first editors (Tab. 1) were the director of the Central Agency for Meteorology and Geodynamics in Vienna, Carl Jelinek (1822-1876) and the young teacher Julius Hann (1839-1921) who carried out meteorological studies alongside his profession at that time. Jelinek had asked him for support. On the title page of the first issue of May 1, 1866 both were named, but in 1867 - for an unknown reason - only Jelinek's name was given. Hann qualified as a professor (habilitation) 
Table 1: Journal editors (Editor-in-chief in bold face letters, deputies in italics) of Meteorologische Zeitschrift and their predecessors.

\begin{tabular}{|c|c|c|c|}
\hline Period & \multicolumn{3}{|c|}{ Editor } \\
\hline & $\begin{array}{l}\text { Zeitschr. österr. Ges. } \\
\text { für Meteorologie }\end{array}$ & $\begin{array}{l}\text { Meteorologische } \\
\text { Zeitschrift }\end{array}$ & $\begin{array}{l}\text { Beiträge / } \\
\text { Contributions }\end{array}$ \\
\hline $1866-1876$ & \multirow{3}{*}{ J. von Hann } & & \\
\hline $1877-1883$ & & & \\
\hline $1884-1885$ & & W. Köppen & \\
\hline $1886-1891$ & \multicolumn{2}{|c|}{ J. von Hann, W. Köppen } & \\
\hline $1892-1903$ & \multirow{2}{*}{\multicolumn{2}{|c|}{ J. von Hann, G. Hellmann }} & \\
\hline 1904-1907 & & & \multirow{2}{*}{ R. Aßmann, H. Hergesell } \\
\hline $1908-1920$ & \multicolumn{2}{|c|}{ J. von Hann, R. Süring } & \\
\hline $1921-1930$ & \multirow{2}{*}{\multicolumn{2}{|c|}{$\begin{array}{l}\text { F.M. Exner, R. Süring } \\
\text { W. Schmidt, R. Süring }\end{array}$}} & \multirow{2}{*}{ H. Hergesell } \\
\hline $1931-1936$ & & & \\
\hline $1937-1944$ & \multirow{2}{*}{\multicolumn{2}{|c|}{ F. Steinhauser, R. Süring }} & \multirow{2}{*}{$\begin{array}{l}\text { W. Georgii, Duckert, } \\
\text { Hergesell (only 38) }\end{array}$} \\
\hline \multirow[t]{2}{*}{1945} & & & \\
\hline & $\begin{array}{l}\text { Zeitschrift für } \\
\text { Meteorologie } \\
\end{array}$ & \begin{tabular}{|l|}
$\begin{array}{l}\text { Meteorologische } \\
\text { Rundschau }\end{array}$ \\
\end{tabular} & \multirow{5}{*}{ - not published - } \\
\hline 1946 & \multirow{2}{*}{ R. Süring } & & \\
\hline 1947-1950 & & \multirow{7}{*}{ K. Keil } & \\
\hline $1950-1952$ & W. König & & \\
\hline $1952-1956$ & $\begin{array}{l}\text { H. Phillips, E. Heyer/ } \\
\text { R. Knepple, R. Haake }\end{array}$ & & \\
\hline 1957-1962 & $\begin{array}{l}\text { H. Ertel (not 60-62), } \\
\text { H. Phillips, R. Haake }\end{array}$ & & \multirow[t]{2}{*}{ W. Georgii, Koschmieder } \\
\hline 1963-1964 & \multirow{4}{*}{$\begin{array}{l}\text { H. Ertel, A.Lauter, } \\
\text { R. Haake }\end{array}$} & & \\
\hline 1964-1967 & & & \begin{tabular}{|l|} 
Brocks, Fortak, \\
Kleinschmidt, Möller, van \\
Mieghem
\end{tabular} \\
\hline 1968-1969 & & & \multirow{2}{*}{ H. Hinzpeter } \\
\hline $1970-1972$ & & \multirow{3}{*}{ C. Diem } & \\
\hline $1972-1975$ & \multirow{3}{*}{$\begin{array}{l}\text { K. Bernhardt, A. Lauter, } \\
\text { H. Pleiß, since } 79 \text { with } \\
\text { W. Häuser, R. Haake }\end{array}$} & & \\
\hline $1976-1979$ & & & \multirow{3}{*}{ H. Kraus } \\
\hline 1980-1984 & & \multirow{3}{*}{ R. Roth } & \\
\hline$\frac{1985-1987}{1988-1991}$ & \multirow{2}{*}{$\begin{array}{l}\text { K. Bernhardt, W. Häuser, } \\
\text { H. Pleiß, J.Taubenheim, } \\
\text { R. Haake }\end{array}$} & & \\
\hline \multirow{2}{*}{ 1988-1991 } & & & F. Herbert \\
\hline & Meteorolog & sche Zeitschrift & \\
\hline $1992-1993$ & H. Pichler, H. Richner, R. R & h, J. Taubenheim, S. Emeis" & D. Etling \\
\hline $1994-1995$ & $\begin{array}{l}\text { M. Kerschgens, H. Pichler, I } \\
\text { S. Emeis }\end{array}$ & Richner, J. Taubenheim, & \\
\hline 1996-1997 & M. Kerschgens, H. Pichler, H & Richner, G. Tetzlaff, S. Emeis ${ }^{*}$ & J. Heintzenberg \\
\hline 1998-1999 & P. Speth, M. Hantel, H. Rich & er, G. Tetzlaff, S. Emeis" & \\
\hline & & Meteorologische Zeitschr & \\
\hline 2000 & M. Kerschgens, M. Clausse & M. Hantel, H. Richner, R. Sause & \\
\hline $2001-2002$ & M. Kerschgens, M. Clausse & M. Furger, M. Hantel, R. Sauser & \\
\hline $2003-2004$ & M. Hantel, A. Chlond, M. C & aussen, M. Furger, R. Sausen & \\
\hline $2005-2006$ & M. Hantel, A. Chlond, M. F & ger, A. Hense, R. Sausen & \\
\hline 2007 & V. Wulfmeyer, S. Brönnima & n, M. Ehrendorfer, S. Emeis, A. & se, R. Sausen \\
\hline 2008 & V. Wulfmeyer, F. Berger, S & Brönnimann, S. Emeis, L. Haimb & er, A. Hense, H. Schlünzen \\
\hline
\end{tabular}

$\S$ verantwortlicher Redakteur (manag. ed.) ${ }^{*}$ verantwortlicher Schriftleiter (executive editor)

in 1868 and became professor in 1873. After Jelinek's death Hann took over the presidency of the Central Agency for the next 20 years and continued the publication of the journal solely. It was the aim of the publishers and editors - as it was stated on page 13 of the first volume - to follow the pattern given by the Proceedings of the British Meteorological Society, the Annuaire de la Société Météorologique de France and the Bulletino meteorologico dell'Osservatorio del Collegio Romano.

125 years ago, in 1883, the DMG was founded in Hamburg and started the publication of Meteorologische Zeitschrift in 1884, edited by the head of the department of maritime meteorology of the Deutsche Seewarte in Hamburg, Wladimir Köppen (1846-1940). The meteo- rological activities of the DMG in Germany were not unrivalled at that time. Already two years earlier, in 1881, Richard Aßmann had founded his society for agricultural meteorology (Verein für landwirtschaftliche Wetterkunde) and published his monthly journal on practical meteorology (Monatsschrift für praktische Witterungskunde). This jounal, which had appeared since 1882, was renamed as The Weather (Das Wetter) in 1884 (EMEIs, 2008). From 1928 on until its cessation in 1944 it appeared under the title Zeitschrift für angewandte Meteorologie Das Wetter (see also Fig. 1). While Aßmann's publication was devoted to popular science, Meteorologische Zeitschrift and the Austrian journal mentioned above were pure scientific journals. 


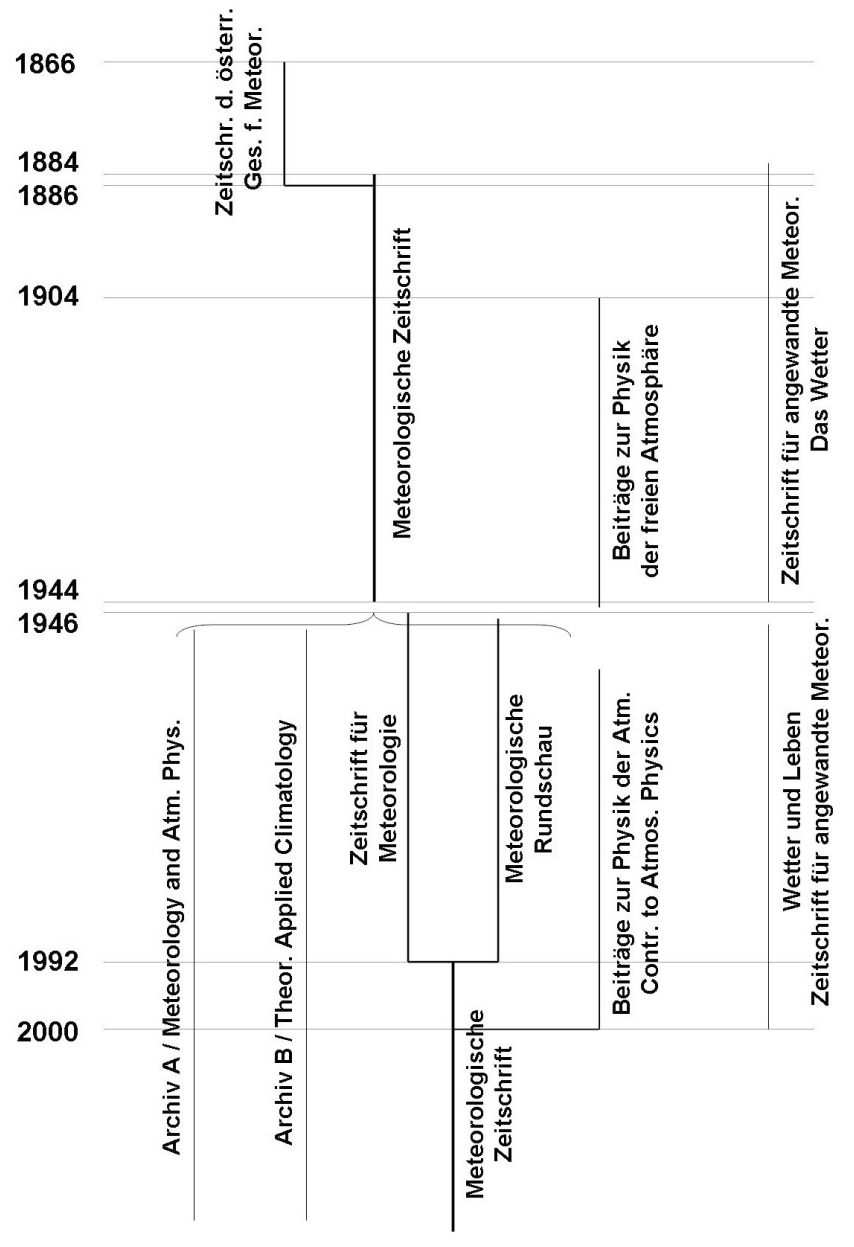

Figure 1: Meteorological journals in Austria and Germany from 1866 until today.

\section{Joint Austrian-German publication from 1886 until 1944}

Already shortly after the foundation of the DMG, the Austrian and the German Meteorological Societies agreed to comply with the request of the German Society (PICHLER, 1990) and to merge their scientific journals. It was decided that one member of each Society would be an editor of the joint journal. From 1886 on Meteorologische Zeitschrift appeared under the editorship of Hann and Köppen. In a subtitle the numbering of the original Austrian journal was continued using roman numerals. Thus the first joint volume simultaneously was the XXI volume of the Austrian journal. This double numeration had to be ceased due to the political developments in March 1938. The additionally planned unification of the two Meteorological Societies in 1939 was abandoned when World War II broke out (PICHLER, 1990).

In 1904 a third German-language journal was founded besides the scientific journal Meteorologische Zeitschrift and the popular journal Das Wetter: Richard Aßmann

\section{$\underbrace{\text { IBand, }}$

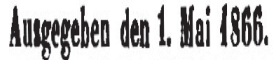

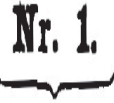 ZEITSCHRIPT}

der

\section{österreichischen Gesellschaft}

fiur

\section{VIETEOROLOGIL.}

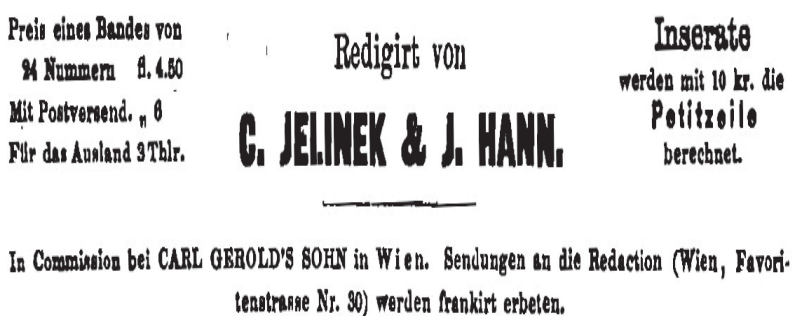

Figure 2: Title of the first issue of Zeitschrift der österreichischen Gesellschaft für Meteorologie on May 1, 1866.

and Hugo Hergesell founded the Beiträge zur Physik der freien Atmosphäre (Contributions to the physics of the free atmosphere). This scientific journal was devoted - as it was said in the subtitle - to the exploration of the higher layers of the atmosphere. It existed, with an interruption between 1946 and 1956, until 1999. Additionally, Richard Aßmann together with Karl Schell for some years edited a journal of the German Physical Society: the Fortschritte der Physik (PEPPLER, 1918).

The outstanding personalities within the 59 years of the joint publication of Meteorologische Zeitschrift were Julius von Hann and Reinhard Süring (1866-1950). Including the years of co-editorship with Jelinek, Hann conducted the scientific journals of the two Societies for 55 years. In 1908 Reinhard Süring took over the position of the German editor within the double head of the journal from Gustav Hellmann (1854-1939) and presided the journal until its discontinuation in 1944. He coined the journal for 37 years. Finally, Ferdinand Steinhauser (1905-1991) was the Austrian co-editor together with Reinhard Süring. In the first 61 years of its existence Meteorologische Zeitschrift had rapidly become one of the leading European journals for Meteorology and Climatology and enjoyed a high reputation (PICHLER, 1990). 


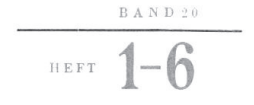

\section{Zeitschrift für} Meteorologie

Figure 3: Title of an issue of Zeitschrift für Meteorologie in the year 1968.

\section{The period of the Cold War and its aftermath from 1946 to 1991}

With the end of World War II not only Meteorologische Zeitschrift itself had to discontinue its appearance but also the tight cooperation between the Austrian and German Meteorological Society in the field of publications had to stop. Between 1946 and 1949, altogether five new journals were founded in the two German states and in Austria (Fig. 1). The first one was the Zeitschrift für Meteorologie (Fig. 3) in the eastern part of Germany (GDR). The first editor was the 81-year-old director of the Meteorological Observatory in Potsdam, Reinhard Süring, who represented a continuous editorial work in Germany after the war. From 1957 on the Meteorological Society in the GDR acted as the official publisher. In the western part of Germany the Meteorologische Rundschau was founded with Karl Keil as the first editor in order to fill the gap which had been left since the war (Fig. 4). In Austria Ferdinand Steinhauser continued his editorial work and founded the two series of the Archiv für Meteorologie, Geophysik und Bioklimatologie together with W. Mörikofer. Series A dealt with meteorology and geophysics, series B with climatology, environmental meteorology and radiation research. In 1948 the ÖGM additionally founded the more popular journal Wetter und Leben - Zeitschrift für praktische Bioklimatologie (Journal for practical bioclimatology, from 1964 on the subtitle changed to Zeitschrift für angewandte Meteorologie (Journal for Applied Meteorology)) with Franz Sauberer as first editor. This last journal which continued to some extent the tradition of Aßmann existed until the year 2000 .

In $1957 \mathrm{~W}$. Georgii, one of the pre-war editors, continued the Beiträge zur Physik der freien Atmosphäre with a slightly changed title (the word "freien" was skipped). In 1969 this journal was officially renamed as Contribution to Atmospheric Physics (keeping the former German title as a subtitle, Fig. 5). This was the first meteorological journal from a German-speaking country that switched to a title in English, the now dominating lan-

\section{Meteorologische Rundschau}

Herausgegeben von Rainer Roth

Beiräte

M. Diem $\cdot$ H. Flohn $\cdot$ H. W. Georgii

L. Hasse $\cdot$ E. Lingelbach $\cdot$ S. Uhlig

44. Jahrgang Heft $1-4$

Figure 4: Title of an issue of Meteorologische Rundschau in the year 1991.

guage for scientific communication. Consequently papers in the Contributions had to be in English from that time on. After the re-foundation of the DMG in 1974 the Contributions and the Rundschau became official publications of the DMG. A thematic division between the two journals was maintained: the Contributions published the more theoretical papers, the Rundschau the more synoptic and climatological papers. The two series of the Archiv in Austria changed their titles into English in 1981. From 1986 onwards series A has been published as Meteorology and Atmospheric Physics, series $\mathrm{B}$ as Theoretical and Applied Climatology.

\section{Re-foundation of Meteorologische Zeitschrift 1992 to 1999}

The reunification of Germany brought many changes also for the meteorological community in this country. The Meteorological Societies of Eastern and Western Germany merged and thereafter published three scientific meteorological journals: the Meteorologische Rundschau, edited by Rainer Roth, the Contributions to Atmospheric Physics, edited by Fritz Herbert and the Zeitschrift für Meteorologie under the joint editorship of K. Bernhardt, W. Häuser, H. Pleiß and J. Taubenheim. In order to rectify this situation, the re-foundation of the Meteorologische Zeitschrift was proposed. Also the ÖGM in Austria had the wish to reanimate this journal with its rich tradition. In order to avoid possible political misinterpretations, which an Austrian-German cooperation could imply having the year 1938 in mind, Helmut Pichler suggested incorporating the Swiss Meteorological Society (SGM) in the re-foundation. The 1916founded and in the meantime repeatedly renamed SGM agreed, also because it did not publish any journal of its own.

So, in 1992 Meteorologische Zeitschrift was refounded as a joint publication of the Austrian, Swiss, and German Meteorological Societies by merging the Zeitschrift für Meteorologie and the Meteorologische Rundschau. For specific legal reasons the numbering of volumes had to be started with number 1 again (from 


\section{Vol. 72 Contributions to Nov.1999 Atmospheric Physics}

\section{Beiträge zur Physik der Atmosphäre}

\author{
A publication of the \\ Deutsche Meteorologische Gesellschaft
}

Figure 5: Title of an issue of Contributions to Atmospheric Physics in the year 1999 .

1992 to 1999 with the addition "Neue Folge" (new series)). Nowadays identical volume numbers can only be differentiated by looking at the publication year. The current volume published in 2008, for example, has the same volume number 17 as the volume published in 1900. Although the original German title was preserved it was decided that English should become the main language in this journal to enhance the international visibility of the journal and to foster its consideration in the Science Citation Index. Consequently the number of papers in the English language rose from about $35 \%$ in 1992 to 70 to $90 \%$ in the years 1996 to 1999 (Tab. 2).

The three publishing Societies SGM, ÖGM, and DMG agreed that the DMG should be entitled to name two editors and the other two Societies one editor each. For the communication with the publisher Gebrüder Borntraeger in Stuttgart and for the coordination among the four equal editors the new position of an executive editor (in German: verantwortlicher Schriftleiter) was created which was taken over by Stefan Emeis. The other journal of the DMG (Contribution to Atmospheric Physics) and the three Austrian journals Wetter und Leben, Meteorology and Atmospheric Physics, and Theoretical and Applied Climatology continued their separate publications.

\section{Meteorologische Zeitschrift today}

At the end of the $90^{\mathrm{S}}$ of the preceding century it became clear that the DMG was not able to run two journals successfully in parallel. Therefore another merger was prepared. Finally, it was decided to unite Contribution to Atmospheric Physics with Meteorologische Zeitschrift keeping the tradition of the old name of the latter which had been in use already more than one hundred years ago. With this latest merger Meteorologische Zeitschrift (Fig. 6) now also carries and continues the heritage of Richard Aßmann. Furthermore, from the year 2000 onwards, all papers have to be published in English with the only exception concerning the review of books written in German. Additionally, it was agreed that the DMG had to appoint three editors, whereas the

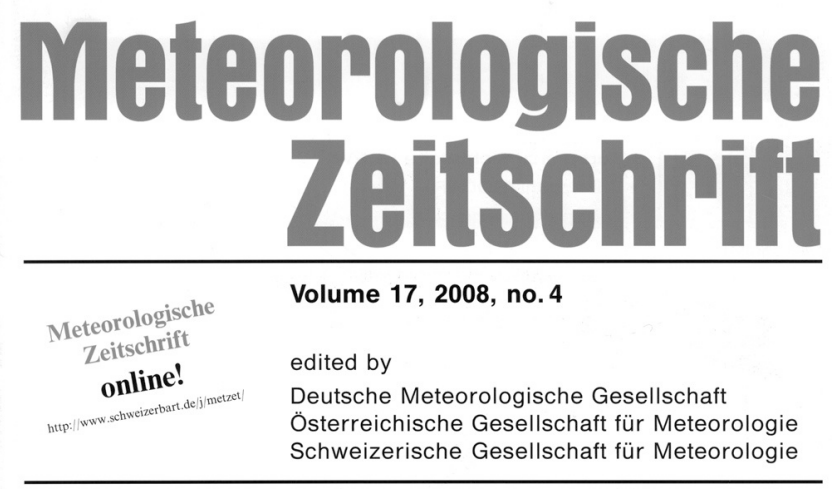

Figure 6: Title of the issue of Meteorologischen Zeitschrift from February 2008.

two other Societies continued to appoint one editor each. For the first time in the long history of Meteorologische Zeitschrift one of the editors was chosen to be a true Editor-in-Chief. The first editor to hold this position was Michael Kerschgens (DMG) and for the years 2003 to 2006 Michael Hantel (ÖGM) took over. Currently Volker Wulfmeyer is in this position. In 2006 and 2007, due to the increasing number of submitted papers, one additional editor was appointed in each of these years; bringing the total number of editors now to seven persons. Since 2007, the Editor-in-Chief has additionally been supported by a Deputy Editor-in-Chief. This position has been taken over by Stefan Emeis due to his experience in running this journal from 1992 to 1999.

In the recent years several new and helpful features have been introduced to make Meteorologische Zeitschrift even more attractive. Besides the citation of Meteorologische Zeitschrift as Meteorol. Z., the acronym MetZet was introduced for communication, in order to indicate that MetZet is an Englisch speaking journal. The most important improvements are:

- Online access to all papers

- Online submission and review system

- Open access

- New webpage

- The Classical Paper Series

Online access: All readers who either have a personal subscription or an institutional access via their employer can now access all papers in Meteorologische Zeitschrift via the IngentaConnect service ${ }^{1}$ from volume 10 (February 2001) onwards. Open access articles can be read by everybody. The table of contents of the available issues can be accessed via www.ingentaconnect.com /content/schweiz/mz. All papers published in Meteorologische Zeitschrift since February 2001 obtain a DOI

${ }^{1}$ www.ingentaconnect.com/ 
Table 2: Percentage of papers written in English in Meteorologische Zeitschrift in the years 1992 to 1999.

\begin{tabular}{|l|l|l|l|l|l|l|l|l|}
\hline Jahr & 1992 & 1993 & 1994 & 1995 & 1996 & 1997 & 1998 & 1999 \\
\hline & 0.353 & 0.710 & 0.679 & 0.600 & 0.788 & 0.714 & 0.894 & 0.737 \\
\hline
\end{tabular}

Table 3: Impact factor (calculated by ISI Web of Knowledge (Thompson Scientific)) for Meteorologische Zeitschrift for the years 1999 to 2007.

\begin{tabular}{|l|l|l|l|l|l|l|l|l|l|}
\hline Jahr & 1999 & 2000 & 2001 & 2002 & 2003 & 2004 & 2005 & 2006 & 2007 \\
\hline IF & 0.427 & 0.368 & 0.818 & 0.500 & 0.708 & 0.812 & 0.833 & 1.007 & 0.986 \\
\hline
\end{tabular}

(digital object identifier) $)^{2}$ number which allows locating the paper in the web. The user just has to enter http://dx.doi.org/ $<$ DOI number $>$ into the search line of his internet browser in order to get at least access to the abstract of the respective paper.

Online Review System: In summer 2008, the new online manuscript submission and review system has become operational, which has been set up by a team consisting of the Editor-in-Chief and the Schweizerbart Publishing Company. It helps authors and reviewers to follow and to document in detail their submissions and tasks through the review and production procedure. $\mathrm{Fu}$ ture submission to Meteorologische Zeitschrift should be made via https://www.schweizerbart.de/submit/metz/ index.php/metz/about

Open Access: The financial basis of the journal is presently being changed from the traditional model where the reader has to pay to a new model which shifts the cost burden to the authors. In an alternative to the mandatory page charges, from the seventh page onwards the authors can nowadays choose the Optional Open Access (OOA) model and thereby provide a cost-free access for all readers in the world-wide web. The latter model is better adapted to the still increasing use of the internet by scientists.

MetZet Website: All relevant information for authors and readers has been integrated into a new webpage which offers the pertinent links at www.metzet.de

MetZet Classic Paper Series: Older papers (before February 2001) from Meteorologische Zeitschrift are presently only available in printed form from libraries. Some of them have had widespread influence and are still frequently being cited. The access to seminal papers before 1992 is additionally limited for a wider international audience because those papers have usually been written in German. Therefore the editors of Meteorologische Zeitschrift have decided to start a series of re-publication of Classical papers coordinated by Stefan BRÖNNIMANN. Selected papers will be translated into English and will be accompanied by an introductory paper which puts the old paper into the modern context.

\footnotetext{
${ }^{2}$ Trademark of the International DOI Foundation

(www.doi.org/welcome.html)
}

Tab. 4 gives an overview on the Classical papers which are planned for a re-publication in the next years.

\section{Most-cited papers from Meteorologische Zeitschrift}

The Science Citation Index of ISI (http://isiknowledge. com) offers the possibility to find the most-cited papers since the re-foundation of the journal. Following these evaluations Schumann's paper from $1996^{3}$ on "Conditions for contrail formation from aircraft exhausts" is leading with now more than 80 quotations. The ranking platform of Elsevier, Scopus (http://www.scopus.com), even counts more than 100 quotations for this paper. In the years after the latest merger with the Contributions, three papers with more than 25 quotations can be observed in the ISI statistics: SAUSEN et al. (2005) on "Aviation radiative forcing in 2000: An update on IPCC (1999)", ZORITA et al. (2004) on "Climate evolution in the last five centuries simulated by an atmosphere-ocean model: global temperatures, the North Atlantic Oscillation and the Late Maunder Minimum", and RAASCH and SCHRÖTER (2001) on "PALM - A large-eddy simulation model performing on massively parallel computers". Following Scopus the ranking is somewhat different but the paper by SAUSEN et al. is leading with nearly 50 quotations. These differences in citation statistics should remind potential users to read them with some care.

For the first publication period of Meteorologische Zeitschrift from 1884 and 1944 no statistics from ISI or Scopus are available. Only Harzing's free software "Publish or Perish" (www.harzing.com) gives some indications based on the data of Google Scholar (http://scholar.google.de). Accordingly, the paper by Vilhelm BJERKNES (1904) ${ }^{4}$ on "Das Problem der Wettervorhersage, betrachtet vom Standpunkte der Mechanik und Physik" is the most cited paper from that period today. Attention is also still paid to two papers

\footnotetext{
${ }^{3}$ See Appendix for citations of this and the following papers which were published after 1992.

${ }^{4}$ The citations for this and the following papers published before 1992 are given in Tab. 4.
} 
Table 4: Planned re-publications in the Classic papers series of Meteorologische Zeitschrift. Papers under the several subject headings are given in the order of their appearance.

\begin{tabular}{|c|c|}
\hline Subject & Papers \\
\hline $\begin{array}{l}\text { Aerosols and } \\
\text { biomass burning }\end{array}$ & $\begin{array}{l}\text { VON DANCKELMAN, A., 1884: Die Bewölkungsverhältnisse des } \\
\text { südwestlichen Afrikas. - Meteorol. Z. 1, 301-311. }\end{array}$ \\
\hline $\begin{array}{l}\text { North Atlantic } \\
\text { Oscillation and } \\
\text { European climate }\end{array}$ & $\begin{array}{l}\text { HANN J., 1890: Zur Witterungsgeschichte von Nord-Grönland, Westküste. . } \\
\text { - Meteorol. Z. 7, 109-115. }\end{array}$ \\
\hline Föhn & $\begin{array}{l}\text { HANN, J., 1885: Einige Bemerkungen zur Entwicklungsgeschichte der } \\
\text { Ansichten über den Ursprung des Föhns. - Meteorol. Z. 2, 393-399. } \\
\text { FICKER, H., 1910: Über die Entstehung der Föhnwinde auf der Nordseite } \\
\text { der Alpen. . - Meteorol. Z. 27, 439-451. }\end{array}$ \\
\hline Arctic climate & $\begin{array}{l}\text { FLOHN H., 1952: Zur Aerologie der Polargebiete. - Meteorol. Rdsch. 5, } \\
81-87,121-128 .\end{array}$ \\
\hline Climatology & $\begin{array}{l}\text { KÖPPEN, W., 1884: Die Wärmezonen der Erde, nach der Dauer der heissen, } \\
\text { gemässigten und kalten Zeit und nach der Wirkung der Wärme auf die } \\
\text { organische Welt betrachtet. - Meteorol. Z. 1, 215-226. }\end{array}$ \\
\hline Radiation & $\begin{array}{l}\text { ÅNGSTROM, A.K., 1916: Über die Gegenstrahlung der Atmosphäre. . } \\
\text { - Meteorol. Z. 33, 529-538. }\end{array}$ \\
\hline Microphysics & $\begin{array}{l}\text { FINDEISEN, W., 1938: Die kolloidmeteorologischen Vorgänge bei der } \\
\text { Niederschlagsbildung. . - Meteorol. Z. 55, 121-133. }\end{array}$ \\
\hline $\begin{array}{l}\text { Atmospheric } \\
\text { Dynamics }\end{array}$ & $\begin{array}{l}\text { BJERKNES, V., 1904: Das Problem der Wettervorhersage, betrachtet vom } \\
\text { Standpunkte der Mechanik und der Physik. - Meteorol. Z. 21, 1-7. } \\
\text { MARGULES, M., 1906: Über Temperaturschichtung in stationär bewegter } \\
\text { und in ruhender Luft. . - Meteorol. Z., Hann-Band zum vierzigjährigen } \\
\text { Redaktionsjubiläum J. Hann's von Freunden und Kollegen gewidmet*, } \\
\text { 243-254. } \\
\text { EXNER, F.M., 1908: Über eine erste Annäherung zur Vorausberechnung } \\
\text { synoptischer Wetterkarten. - Meteorol. Z. 25, 465-468. } \\
\text { EXNER, F.M., 1914: Über monatliche Witterungsanomalien auf der } \\
\text { nördlichen Halbkugel im Winter. - Meteorol. Z. 31, 104-109. } \\
\text { FICKER, H., 1920: Der Einfluss der Alpen auf Fallgebiete des Luftdrucks } \\
\text { und die Entwicklung von Depressionen über dem Mittelmeer. } \\
\text { - Meteorol. Z. 37, 350-363. } \\
\text { SCHERHAG, R., 1934: Zur Theorie der Hoch- und Tiefdruckgebiete. } \\
\text { - Meteorol. Z. 51, 129-138. } \\
\text { BJERKNES, J., 1937: Theorie der aussertropischen Zyklonenbildung. } \\
\text { - Meteorol. Z. 54, 462-466. }\end{array}$ \\
\hline Aerology & $\begin{array}{l}\text { SÜRING, R., 1910: A. Bersons Bericht über die aerologische Expedition des } \\
\text { königlichen aeronautischen Observatoriums nach Ostafrika im Jahre } 1908 . \\
\text { - Meteorol. Z. 27, 536-542. }\end{array}$ \\
\hline
\end{tabular}

*Supplement to volume 23 , dedicated to J. Hann's $40^{\text {th }}$ editorial anniversary by his friends and colleagues.

from the first volume in 1884: Wladimir KöPPEN's article "Die Wärmezonen der Erde, nach der Dauer der heissen, gemässigten und kalten Zeit und nach der Wirkung der Wärme auf die organische Welt betrachtet", and Alexander VON DANCKELMAN's paper on "Die Bewölkungsverhältnisse des südwestlichen Africas".

Harzing's statistics for the period between 1884 and 1944 does not yield a fair picture of the importance and impact of the Meteorologische Zeitschrift during this first period of its existence. Many renowned Austrian, German, and Scandinavian meteorologists published their work in this journal. Just a few can be named here to illustrate the spectrum of papers ranging from HANN's (1885) "Einige Bemerkungen zur Entwicklungsgeschichte der Ansichten über den Ursprung des Föhns", over EXNER's (1908) "Über eine erste Annäherung zur Vorausberechnung synoptischer Wet- terkarten" to ERTEL's $(1942)^{5}$ paper on "Ein neuer hydrodynamischer Wirbelsatz". The first two of these three papers are among the seminal papers which are planned to be re-published in the Classical paper series of Meteorologische Zeitschrift (see Tab. 4). The first paper in the Classical paper series will probably be the paper by VON DANCKELMAN (1884).

\section{Changes in publications printed in Meteorologische Zeitschrift}

Looking at the papers published in Meteorologische Zeitschrift during the last 143 years, a substantial change in the style of publishing is revealed. In 1867 a typical

${ }^{5}$ See Appendix. This paper is not included in the Classic paper series because an English translation has recently been published in the special issue of Meteorologische Zeitschrift on Hans Ertel's work (see Tab. 5), Meteorol. Z. 13 (2004), 533-537 (DOI: 10.1127/0941-2948/2004/0013-0527). 
Table 5: Special issues of Meteorologische Zeitschrift since its re-foundation in 1992.

\begin{tabular}{|c|c|c|c|c|}
\hline Year & Vol & No & Title & (Guest) Editor(s) \\
\hline 1992 & 1 & 1 & $\begin{array}{l}\text { Contributions to the Global Precipitation } \\
\text { Climatology Centre }\end{array}$ & $\begin{array}{l}\text { H. Pichler, H. Richner, R. Roth, } \\
\text { J. Taubenheim }\end{array}$ \\
\hline 1993 & 2 & 4 & POLLUMET Workshop, Basel, October 1992 & J. Staehelin, H. Richner \\
\hline 1994 & 3 & 3 & METTOOLS II, Hohenheim, 1993 & W.-J. Kost \\
\hline 1996 & 5 & 5 & $\begin{array}{l}\text { Results from the Integrated Research } \\
\text { Programme SANA }\end{array}$ & W. Seiler \\
\hline 1997 & 6 & 6 & History of Meteorology & C. Lüdecke, H. Volkert \\
\hline 1998 & 7 & 1 & METTOOLS III, Freiburg, 1997 & H. Mayer \\
\hline 1998 & 7 & $5+6$ & $\begin{array}{l}\text { Contributions to the COST-76 Profiler Workshop, } \\
\text { Engelberg, } 1997\end{array}$ & W.A. Monna \\
\hline 2000 & 9 & $1+2$ & $\begin{array}{l}\text { Selected papers from the "Second Study } \\
\text { Conference on BALTEX (Baltic Sea } \\
\text { Experiment)", Juliusruh, } 1998\end{array}$ & E. Raschke \\
\hline 2001 & 10 & 3 & $\begin{array}{l}\text { Solar eclipse, } 11 \text { August } 1999 \text { - the BAYSOFI } \\
\text { campaign }\end{array}$ & S. Emeis \\
\hline 2001 & 10 & 4 & METTOOLS IV, Stuttgart, 2000 & U. Reuter \\
\hline 2001 & 10 & 6 & COST-76 Wind profiler radar & W.A. Monna \\
\hline 2002 & 11 & 1 & $\begin{array}{l}\text { HYPAM (remote sensing of Hydrometeorological } \\
\text { Parameters by Microwave radiometry) }\end{array}$ & H. Grassl \\
\hline 2002 & 11 & 3 & $\begin{array}{l}\text { AEROCHEM II (Modelling the impact of aircraft } \\
\text { emissions on ozone and other chemical } \\
\text { compounds in the atmosphere) }\end{array}$ & M. Furger \\
\hline 2002 & 11 & 4 & Honouring the memory of Hans Hinzpeter & A. Chlond, H. Grassl \\
\hline 2004 & 13 & $1+2+3$ & ICAM/MAP'03, Brig, 2003 & M. Furger, A. Rossa, C. Schwierz \\
\hline 2004 & 13 & 5 & METTOOLS V, Essen, 2003 & W. Kuttler \\
\hline 2004 & 13 & 6 & $\begin{array}{l}\text { Hans Ertel and potential vorticity - a century of } \\
\text { geophysical fluid dynamics }\end{array}$ & M. Claussen, M. Hantel \\
\hline 2005 & 14 & 2 & Biometeorology, Dresden, 2003 & $\begin{array}{l}\text { C. Bernhofer, V. Goldberg, } \\
\text { M. Hantel }\end{array}$ \\
\hline 2005 & 14 & 4 & $\begin{array}{l}\text { Aviation, Atmosphere and Climate, } \\
\text { Friedrichshafen, } 2003\end{array}$ & R. Sausen, M. Hantel \\
\hline 2005 & 14 & 5 & $\begin{array}{l}\text { Meteorological Observatory Lindenberg - } 100 \\
\text { years }\end{array}$ & F.H. Berger, M. Hantel \\
\hline 2005 & 14 & 6 & $\begin{array}{l}\text { SFB } 512 \text { "Cyclones and the North Atlantic } \\
\text { climate system" }\end{array}$ & B. Brümmer, M. Hantel \\
\hline 2006 & 15 & 1 & $\begin{array}{l}\text { COST } 720 \text { TUC (Temperature,hUmidity, and } \\
\text { Cloud profiling) }\end{array}$ & D. Ruffieux, M. Furger \\
\hline 2006 & 15 & 2 & ICAM/MAP2005, Zadar, 2005 & $\begin{array}{l}\text { B. Grisogono, B. Ivančan-Picek, } \\
\text { M. Furger }\end{array}$ \\
\hline 2006 & 15 & 3 & $\begin{array}{l}\text { Thematic Corner: Dynamics of the Middle } \\
\text { Atmosphere }\end{array}$ & U. Langematz, R. Sausen \\
\hline 2006 & 15 & 4 & New aspects of geophysical fluid dynamics & $\begin{array}{l}\text { U. Harlander, A. Hense, A. Will, } \\
\text { M. Kurgansky }\end{array}$ \\
\hline 2006 & 15 & 5 & $\begin{array}{l}\text { VOLTAIRE - Validation of multisensors } \\
\text { precipitation fields and numerical modelling in } \\
\text { Mediterranean test sites }\end{array}$ & S.C. Michaelides, A. Chlond \\
\hline 2007 & 16 & 1 & The weather and climate of Iceland & H. Ólafsson, M. Furger, B. Brümmer \\
\hline 2007 & 16 & $4+5$ & $\begin{array}{l}\text { ISARS } 13 \text { - International Symposium for the } \\
\text { Advancement of Boundary Layer Remote } \\
\text { Sensing, Garmisch, } 2006\end{array}$ & S. Emeis \\
\hline 2007 & 16 & 6 & $\begin{array}{l}\text { Adjoint Applications in Dynamic Meteorology, } \\
\text { Obergurgl, } 2006\end{array}$ & M. Ehrendorfer, R.M. Errico \\
\hline 2008 & 17 & 2 & $\begin{array}{l}\text { Transport, Atmosphere and Climate, Oxford, } \\
2006\end{array}$ & R. Sausen \\
\hline 2008 & 17 & 3 & METTOOLS VI, Garmisch, 2007 & S. Emeis \\
\hline 2008 & 17 & 4 & $\begin{array}{l}\text { Regional climate modelling with COSMO-CLM } \\
\text { (CCLM) }\end{array}$ & B. Rockel, A. Will, A. Hense \\
\hline 2008 & 17 & 5 & The DACH Conference, Hamburg 2007 & H.D. Behr, V. Wulfmeyer \\
\hline
\end{tabular}

paper usually had considerably less than 10 pages (about 275 words per page). For instance, the second volume of the Zeitschrift der österreichischen Gesellschaft für Meteorologie comprised 576 pages. Section headings in a paper were absent. Figures and mathematical expressions were extremely rare. Only few papers contained tables. References were made using footnotes. Thus the papers still widely had the style of a letter (see the be- ginning of the introduction above), written in a very good style and serving for the communication with colleagues. ZоTT (2003) calls this "establishing of contacts among colleagues in order to compensate for scientific and local isolation"; surely an issue in the $19^{\text {th }}$ century. At that time the main justification for a scientific association to publish a journal was to foster the communication among the members of the association and with 
foreign colleagues. For members of such an association it was quite natural to publish in the journal of their own association.

About 140 years later a typical paper covers 10 to 14 pages with about 1000 words each, i.e. the length of a paper has decupled. Mathematical expressions and formulae and five to ten figures are standard today. A volume comprises about 800 pages. The linguistic quality of the papers has somewhat decreased - also due to the mandatory use of English which is the native tongue of only a few authors. Also the limited time available for preparing a publication leaves its mark on the papers.

In addition to the abovementioned alterations another change becomes visible. While communication with colleagues was the main reason for publications in former times, the necessity to document one's own achievements becomes more and more important today. Funding of projects and even the fate of entire institutions may depend on the documentation of previously performed research. The actual communication with colleagues has been partly shifted to other means such as conferences, project meetings, and the internet.

This has consequences for the choice of a journal for publication. Main criteria today are a journal's specialization in the subject the author intends to address and the international visibility of a journal. The request for a benchmark of this visibility has led to the creation of not indisputable single numbers such as the already abovementioned impact factor from ISI. The publishing association is no longer of high interest. This means that the impact factor has meanwhile become an important number also for Meteorologische Zeitschrift (see Tab. 3). A sufficiently high impact factor has turned out to be a major argument for the acquisition of new authors for a journal. These facts reflect the methods of today's national and international funding agencies that more and more rely on the number of publications of a person or a whole institution and on the impact factors of the journals in which these publications appeared. Accordingly, the Meteorologische Zeitschrift has successfully striven to increase its impact factor from 0.43 in 1999 to around 1 since 2006.

Another advance is the increased number of special issues (Tab. 5) of Meteorologische Zeitschrift which form one half to two thirds of the annual volumes. With this editorial policy the journal answers to the abovementioned partial shift of scientific communication to conferences and workshops. The special issues offer a selected and peer-reviewed coverage of these events for the rest of the scientific community.

With these changes, Meteorologische Zeitschrift has moved from a figurehead of the Austrian and German Meteorological Societies which was coined by the characters of their editors to an international service provider for the global meteorological scientific community. National pecularities and the personal character of the editors are more and more overwritten by the competition in the international market for scientific publications. In this sense, the change of Meteorologische Zeitschrift during the last 140 years is just another facet of the globalisation which affects all aspects of our modern life.

\section{Appendix}

Papers having appeared in Meteorologische Zeitschrift and being mentioned in this outline of the history of this journal which are not listed in Tab. 4.

ERTEL, H., 1942: Ein neuer hydrodynamischer Wirbelsatz. - Meteorol. Z. 59, 250-253.

RAASCH, S., M. SCHRÖTER, 2001: PALM - A large-eddy simulation model performing on massively parallel computers. - Meteorol. Z. 10, 363-372 (DOI: 10.1127/0941-2948/2001/00100363).

Sausen, R., I. Isaksen, V. Grewe, D. Hauglustaine, D.S. Lee, G. Myhre, M.O. Köhler, G. Pitari, U. SchumanN, F. StORdal, C. Zerefos, 2005: Aviation radiative forcing in 2000: An update on IPCC (1999). - Meteorol. Z. 14, 555-561 (DOI: 10.1127/0941-2948/2005/0049).

SCHUMANN, U., 1996: On conditions for contrail formation from aircraft exhausts. - Meteorol. Z. 5, 4-23.

Zorita, E., H. von Storch, F.J. GonZalez-Rouco, U. CUBASCH, J. LUTERBACHER, S. LEGUTKE, I. FisCHER-BRUNS, U. SCHLESE, 2004: Climate evolution in the last five centuries simulated by an atmosphere-ocean model: global temperatures, the North Atlantic Oscillation and the Late Maunder Minimum. - Meteorol. Z. 13, 271-289 (DOI: 10.1127/09412948/2004/0013-0271).

\section{Acknowledgments}

My deep thanks go to Marion SCHNEE and KarlHeinz BERNHARDT in Berlin, Walter OBERMILler (Stuttgart), and Franz RUbEL (Vienna) for their willingness to support this paper by searches and interpretations. The reviewers gave valuable hints for the improvement of the paper. The list of the Classic Paper Series to be published in Meteorologische Zeitschrift was compiled by Stefan BRÖNNIMANN.

\section{References}

EMEIS, S., 2006: Das erste Jahrhundert deutschsprachiger meteorologischer Lehrbücher. - Ber. Wissenschaftsgeschichte 29, 39-51.

—, 2008: Richard Assmann. In: Koertge, Noretta, ed. - New Dictionary of Scientific Biography. Detroit, MI: Charles Scribner's Sons, 2008. Vol. 1, 113-118.

PepPler, A., 1918: Richard Assmann †. - Das Wetter 35, 70-79.

PICHLER, H., 1990: Festvortrag "125 Jahre Österreichische Gesellschaft für Meteorologie". - ÖGM Bulletin 90/2, 27.

ZотT, R., 2003: Der Brief und das Blatt. Der Entstehung wissenschaftlicher Zeitschriften aus der Gelehrtenkorrespondenz. - In: PARThey, H., W. UMStätTER (Hrsg.): Wissenschaftliche Zeitschrift und Digitale Bibliothek: Wissenschaftsforschung Jahrbuch 2002. Berlin, Gesellschaft für Wissenschaftsforschung, 47-59. 